\title{
Biology of Some Scolytid Ambrosia Beetles Attacking Tea Plants
}

\section{Growth and Development of Two Species of Scolytid Beetles Reared on Sterilized Tea Plants}

\author{
By Takeshi Kaneko
}

Tea Research Station, Ministry of Agriculture and Forestry, Kanaya, Shizuoka Pref.

There are two species of Xyleborus attacking tea plants in Japan. The tea stem borer, Xyleborus compactus, occurs twice a year and overwinters in tea twig in the adult stage. The first generation appears from July to August and the second from August to September. The adult females usually bore into slender twigs ( 5 to $8 \mathrm{~mm}$ in diameter) just under the surface of tea bush. But in the case of high population density, the beetles also attack trunks at ground level.

Xyleborus germanus occurs twice a year and overwinters in tea root in the adult female. The first generation occurs from June to July and the second from August to September. Adult females bore into tea roots, but scarcely attack tea twigs under field conditions.

According to the observations in the laboratory (KANEKo et al., 1965), the optimum temperature range for the development is from $25^{\circ}$ to $26^{\circ} \mathrm{C}$ in $X$. compactus, and from $21^{\circ}$ to $23^{\circ} \mathrm{C}$ in $X$. germanus. Number of eggs laid by a female ranges from 14 to 16 in $X$. compactus, and from 30 to 80 in $X$. germanus. It takes about 25 days from invasion of the next generation in both species.

In this paper are described the successful rearings of these two species of beetles on steam-sterilized twigs or roots of the tea plants, and their growth pattern and behavior under the artificial rearing conditions.

\section{MATERIALS AND METHODS}

Food For $X$. compactus tea twigs $(7-8 \mathrm{~mm}$ in diameter) were collected in fields, cut into pieces of $12-13 \mathrm{~cm}$ long, and placed in test tubes $(18 \times 180 \mathrm{~mm})$ (Plate I, A). For $X$. germanus fresh tea roots(about $15 \mathrm{~mm}$ in diameter) (Plate I, C) or tea twigs (13-15 $\mathrm{mm}$ in diameter) (Plate $\mathrm{I}, \mathrm{B}$ ) were cut into $8-10 \mathrm{~cm}$ long, and placed in test tubes $(18 \times$ $200 \mathrm{~mm}$ ). The test tubes were stoppered with cotton plugs, and steam-sterilized in an autoclave at $122-123^{\circ} \mathrm{C}$ for $10-15$ minutes. Totally, 200 test tubes for $X$. compactus and 700 tubes for $X$. germanus were prepared.

Insect Hibernating adult females of respective species were collected from fields in December or January, surface-sterilized with 0.1 per cent aqueous solution of mercuric chloride, and inoculated aseptically in the test tubes containing sterilized tea plant materials. Five adult females of $X$. compactus or one female of $X$. germanus were placed in each test tube.

Rearing The rearing wasc arried out in an incubator at temperatures of $25^{\circ}-26^{\circ} \mathrm{C}$ for $X$. compactus and $23^{\circ}-24^{\circ} \mathrm{C}$ for $X$. germanus in the dark. Throughout the rearing period, each 3 to 5 test tubes were chosen at random for daily observation, and growth and development of insects were examined. Tea

(Received for publication, May 21, 1965) 
twigs or roots were taken out from the test tubes and dissected, and the number of individuals in each stage of growth was recorded.

\section{Generation by generation rearing}

Successive rearing was undertaken in $X$. germanus. Upon emergence of active adults, the beetles were collected from the rearing tubes, and placed in petri dishes with a piece of moist filter paper, male to female ratio being adjusted to $1: 2$ or $4: 11$ in a dish. The dishes were kept in an incubator at $23^{\circ}$ $-24^{\circ} \mathrm{C}$ for 4 to 5 days for copulation. The resulting gravid females were inoculated into the test tubes containing steam-sterilized roots or twigs, and the rearing of the second generation was carried out according to the procedures described above.

In order to evaluate the effect of inbreeding and outbreeding on growth and fecundity of successive generations, a series of rearing experiments was programmed. In outbreeding test, female adults emerged from a test tube were mated with male adults from another tube; and in inbreeping test, copula- tion was made among adults from one test tube.

\section{RESULTS AND DISCUSSION}

\section{Xyleborus compactus}

The results obtained from the rearing experiments are summarized in Table 1. The adult females bored into the twigs and made galleries within two days after the inoculation. From 3 to 5 days after the inoculation, ambrosia fungus formed spores on the wall of galleries and females began to oviposit. The oviposition continued for about 5 days, from 5 th to 10 th day after the inoculation. The number of eggs laid by one female ranged from 14 to 16 . The eggs were laid separately or in clusters on the spores of ambrosia fungus. Each cluster consisted of 5 to 6 eggs. The average period of egg stage was 4 days.

The larvae were found in the twigs until 23rd day after the inoculation. The growth rate was variable with individuals, and all stages from egg to last instar larva could

Table 1. Growth and development of Xyleborus compactus fed on steam-sterilized tea twigs (The values show average numbers of individuals per brood)

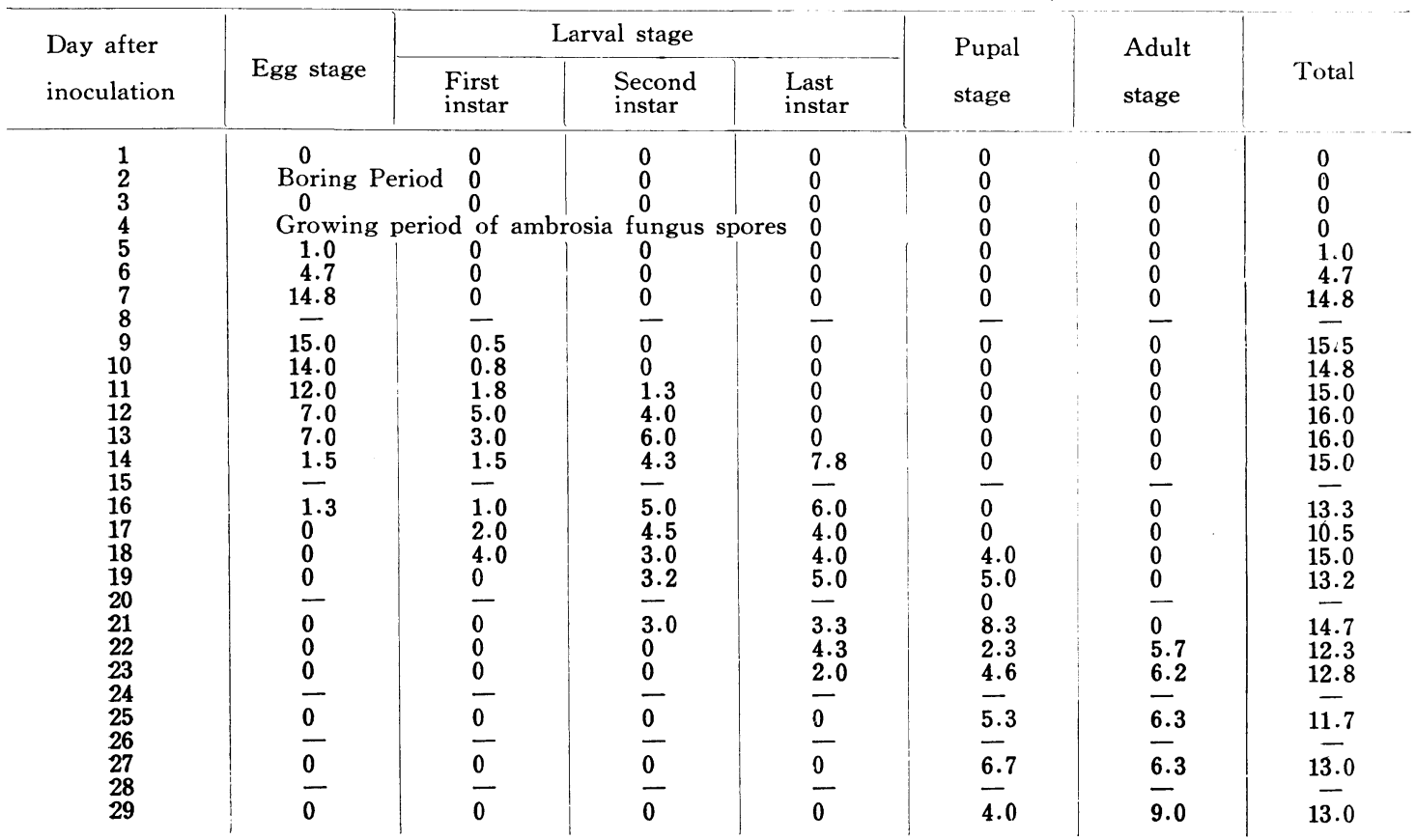


be found in the twigs since 14th to 16th day after the inoculation. The average duration of the first instar larva was 2 days; the second, 3 days; and the last, 4 days. The pupal period was 4 days and normal adult emerged.

The sex ratio of $X$. compactus was found to be about $3: 2$ (우: $\hat{\delta}$ ) in this experiment with steam-sterilized tea twigs, whereas $5: 1$ was recorded in the previous paper (KANEKO et al., 1965).

\section{Xyleborus germanus}

The results of the daily observations on the rearing test of the second generation beetles are shown in Table 2. The total number of eggs produced by one female was assumed to range from 33 to 50 . The duration of egg stage was about 3 days; the first instar larva, 2 days; the second, 2 days; and the last, 3 days. The total duration of larval period thus lasted for 7 days and the pupal period lasted for 5 days. The overall development from egg to adult in an outbreeding test of the second generation required 15 days under laboratory conditions.

The sex ratio of the emerged adult was about $9: 1$ (우: $\hat{\delta}$ ) in the first generation and $8: 1$ in the second generation (Tables

Table 2. Growth and development of Xyleborus germanus fed on steam-sterilized tea twigs. The second generation in the outbreeding test (The values show average numbers of individuals per brood)

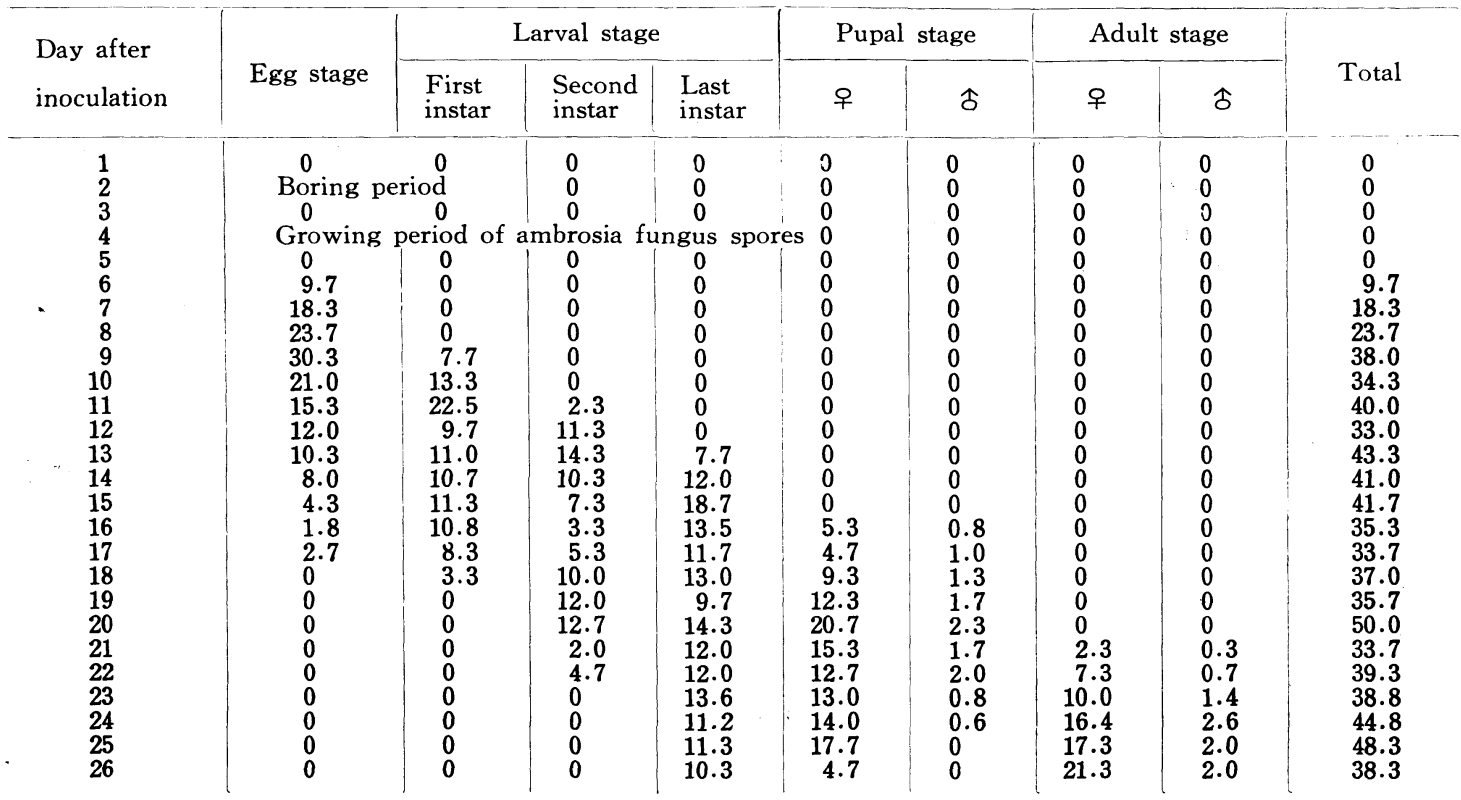

Teble 3. Growth and development of Xyleborus germanus fed on steam-sterilized tea twigs. The first generation (The values show numbers of individuals per brood at 30 th day after inoculation)

\begin{tabular}{|c|c|c|c|c|c|c|c|c|c|c|}
\hline & \multirow{2}{*}{$\begin{array}{l}\text { Repli- } \\
\text { cation }\end{array}$} & \multirow{2}{*}{$\begin{array}{l}\text { Egg } \\
\text { stage }\end{array}$} & \multicolumn{3}{|c|}{ Larval stage } & \multicolumn{2}{|c|}{ Pupal stage } & \multicolumn{2}{|c|}{ Adult stage } & \multirow{2}{*}{ Total } \\
\hline & & & $\begin{array}{l}\text { First } \\
\text { instar }\end{array}$ & $\begin{array}{l}\text { Second } \\
\text { instar }\end{array}$ & $\begin{array}{l}\text { Last.:' } \\
\text { instar }\end{array}$ & 우 & $\hat{0}$ & 우 & $\hat{\delta}$ & \\
\hline $\begin{array}{l}\text { Mean } \\
\text { Maximum } \\
\text { Minimum } \\
\text { Sex ratio }\end{array}$ & 19 & $\begin{array}{l}0 \\
0 \\
0\end{array}$ & $\begin{array}{l}0 \\
0 \\
0\end{array}$ & $\begin{array}{c}2.8 \\
10 \\
2\end{array}$ & $\begin{array}{c}7.8 \\
15 \\
4\end{array}$ & $\begin{array}{c}1.1 \\
13\end{array}$ & $\begin{array}{l}0 \\
0 \\
0 \\
.\end{array}$ & $\begin{array}{l}21.8 \\
33 \\
8 \\
9\end{array}$ & $\begin{array}{l}2.3 \\
4 \\
1 \\
1\end{array}$ & $\begin{array}{l}35.9 \\
46 \\
24\end{array}$ \\
\hline
\end{tabular}


Table 4. Comparison of growth and development between the inbreeding and outbreeding tests. (The values show average numbers of individuals per brood at $22 \mathrm{nd}$ day after inoculation)

\begin{tabular}{l|c|c|c|c|c|c|c|c|c|c|c|}
\hline & $\begin{array}{l}\text { Repli- } \\
\text { cation }\end{array}$ & Egg & \multicolumn{3}{|c|}{ Larval stage } & \multicolumn{2}{c|}{ Pupal stage } & \multicolumn{2}{c|}{ Adult stage } \\
\hline stage & $\begin{array}{l}\text { First } \\
\text { instar }\end{array}$ & $\begin{array}{l}\text { Second } \\
\text { instar }\end{array}$ & $\begin{array}{l}\text { Last } \\
\text { instar }\end{array}$ & 오 & 个 & 오 & Total \\
\hline Inbreeding & 10 & 0.3 & 1.0 & 11.4 & 12.0 & 14.1 & 2.1 & 1.2 & 0.6 & 42.7 \\
Outbreeding & 3 & 0 & 0 & 4.7 & 12.0 & 12.7 & 2.0 & 7.3 & 0.7 & 39.3
\end{tabular}

Table 5. Comparison between sterilized tea roots and tea twigs as food materials of Xyleborus germanus. The first generation. (The values show average numbers of individuals per brood at 25 th day after inoculation).

\begin{tabular}{|c|c|c|c|c|c|c|c|c|c|c|}
\hline \multirow{2}{*}{$\begin{array}{l}\text { Wood } \\
\text { material }\end{array}$} & \multirow{2}{*}{$\begin{array}{l}\text { Repli- } \\
\text { cation }\end{array}$} & \multirow{2}{*}{$\begin{array}{l}\text { Egg } \\
\text { stage }\end{array}$} & \multicolumn{3}{|c|}{ Larval stage } & \multicolumn{2}{|c|}{ Pupal atage } & \multicolumn{2}{|c|}{ Adult stage } & \multirow{2}{*}{ Total } \\
\hline & & & $\begin{array}{l}\text { First } \\
\text { instar }\end{array}$ & $\begin{array}{l}\text { Second } \\
\text { instar }\end{array}$ & $\begin{array}{l}\text { Last } \\
\text { instar }\end{array}$ & 우 & $\hat{\delta}$ & 우 & $\hat{0}$ & \\
\hline Twigs & 6 & 1.5 & 0.5 & 12.0 & 11.0 & 23.3 & 2.5 & 0 & 0 & 40.8 \\
\hline Roots & 5 & 7.0 & 1.2 & 6.8 & 34.4 & 9.2 & 2.8 & 0 & 0 & 61.4 \\
\hline
\end{tabular}

2 and 3$)$,

Under the condition of $23^{\circ}-24^{\circ} \mathrm{C}$, beetles copulated during 4 to 5 days after emergence. It was often observed from outside that the beetles in the test tubes were copulating in the superimposed position, the male above the female and facing the same direction. According to comparison of outbreeding and inbreeding tests on steam sterilized twigs, there was no significant difference in the growth and development of the second generation (Table 4).

Numbers of laid eggs, matured larvae, and newly emerged adults per brood varied with the sort of wood materials. In the case reared on twig, average number of individuals per brood was 40.8 ; while on root as many as 61.4 was recorded (Table 5 ). The beetle seems to prefer root, natural food material, to twig. Without their natural food material, however, they bore into twigs in the rearing tubes and propagate normally. Root is usually more moist than twig, and appears to be favorable for growth of ambrosia fungus spores on which the larvae feed. Desiccation of wood material resulted in decline of growth of ambrosia fungus. The beetles did not necessarily select the wood materials by size or diameter, but they seemed to prefer the root in moderate size, about $15 \mathrm{~mm}$ to $20 \mathrm{~mm}$ in diameter. The mother beetle seems to adjust the number of eggs to be laid according to the space of gallery. The number of eggs laid vary with the diameter and relative humidity of wood. The rate of growth and development of the insect, and number of individuals reaching maturity, seem to vary considerably even in the same climatic conditions. It is reasonable to assume that such variations depend on the growth of ambrosia fungus, as well as on the conditions of wood material.

The mother beetles crawl to and fro in the irregularly branched gallery, and usually take care of broods throughout her life. They always seem to intend to keep the galleries clean, and continue to inoculate ambrosia fungus spores on the wall of galleries during the growing period of larvae. It was observed that the dust of wood material and other refuse were pushed out in soft cylindrical form, which are soon broken down and removed from the entrance of gallery.

Relative humidity in the gallery appeared to be kept as constant as possible under 
Table 6. Growth and development of Xyleborus germanus fed on steam-sterilized tea twigs. The third generation in outbreeding test. The values show average numbers of individuals per brood.

\begin{tabular}{|c|c|c|c|c|c|c|c|c|c|}
\hline \multirow{2}{*}{$\begin{array}{l}\text { Day after } \\
\text { inoculation }\end{array}$} & \multirow{2}{*}{$\begin{array}{l}\text { Egg } \\
\text { stage }\end{array}$} & \multicolumn{3}{|c|}{ Larval stage } & \multicolumn{2}{|c|}{ Pupal stage } & \multicolumn{2}{|c|}{ Adult stage } & \multirow{2}{*}{ Total } \\
\hline & & $\begin{array}{l}\text { First } \\
\text { instar }\end{array}$ & $\begin{array}{l}\text { Second } \\
\text { instar }\end{array}$ & $\begin{array}{l}\text { Last } \\
\text { instar }\end{array}$ & 우 & $\hat{0}$ & 우 & 今 & \\
\hline $\begin{array}{l}12 \\
14 \\
15 \\
17 \\
18 \\
20\end{array}$ & $\begin{array}{r}28.0 \\
18.0 \\
19.5 \\
10 . . \\
3.0 \\
9.0\end{array}$ & $\begin{array}{r}10.0 \\
13.0 \\
14.5 \\
10.0 \\
5.0 \\
6.0\end{array}$ & \begin{tabular}{r}
\multicolumn{1}{c}{0} \\
13.0 \\
7.5 \\
7.0 \\
10.0 \\
6.0
\end{tabular} & $\begin{array}{r}0 \\
0 \\
4.0 \\
7.5 \\
14.5 \\
8.0\end{array}$ & $\begin{array}{l}0 \\
0 \\
0 \\
0 \\
2.0 \\
6.0\end{array}$ & $\begin{array}{l}0 \\
0 \\
0 \\
9 \\
0.5 \\
0\end{array}$ & $\begin{array}{l}0 \\
0 \\
0 \\
0 \\
0 \\
0\end{array}$ & $\begin{array}{l}0 \\
0 \\
0 \\
0 \\
0 \\
0\end{array}$ & $\begin{array}{l}38.0 \\
43.5 \\
45.5 \\
34.5 \\
30.0 \\
35.0\end{array}$ \\
\hline
\end{tabular}

the different temperatures employed. The mother beetle often turns her back to the entrance of gallery and closes the entrance with a sacrifice of her own body.

After emergence, young adult female usually feed on the mycellium of ambrosia fungus growing on the surface of wood material in the test tube.

Virgin adult female was able to puncture the surface of wood material, but only shallow pits were observed, and no growth of ambrosia fungus spores was found there. Generally, growth and development of Xyleborus germanus fed on steam-sterilized tea root and twigs are normal during first two generations, but the growth and vitality of ambrosia fungus spores rapidly decline in the third generation under rearing test conditions (Table 6). Sterilized tea roots and twigs maintaining excellent growth of ambrosia fungus spores accounted to only 20 per cent of total in the third generation. The boring activity of beetles and growth activity of ambrosia fungus, however, were recovered by offering fresh roots as food material. It could be suggested that some stimulus of unknown substance contained in fresh wood material promote the activity of newly-emerged adult female.

\section{SUMMARY}

1. Two species of ambrosia beetles, Xylcborus compactus and Xyleborus germanus, were successfully reared in test tubes under the laboratory conditions. X. compactus was supplied with steam-sterilized tea twigs, and $X$. germanus with steam-sterilized tea roots or tea twigs as focd materials; then the growth and development of the beetles was observed.

2. The overall development of $X$. compactus from egg to adult requires about 17 days at temperature of $25^{\circ}-26^{\circ} \mathrm{C}$. The egg period was about 4 days. The larval period was 9 days (the first instar, 2 days; the second, 3 days; and the last, 4 days). The pupal period was 4 days. The sex ratio in one brood was $3: 2$ (우: 1 ). Approximately 14 to 16 eggs were laid by one female.

3. The overall development of $X$. germanus from egg to adult required 15 days at temperature of $24^{\circ} \mathrm{C}$. The egg period was about 3 days. The larval period was 7 days (the first instar, 2 days; second, 2 days; last, 3 days). The pupal period was 5 days. Sex ratio of emerged adults was $9: 1$ (우: $\hat{\delta}$ ) in the first generation and $8: 1$ (우: $\hat{\delta}$ ) in the second.

4. Growth, development, and oviposition of $X$. germanus varied with the kind of wood material. The beetle seems to prefer root to twig. Roots are more moist than twigs, and may be favorable for growth of ambrosia fungus spores on which the larvae feed.

5. The number of eggs laid by a female of $X$. germanus was ranging from 33 to 50 . The mother beetle adjusts the number of eggs to be laid according to space of her gallery and diameter of wood material. The growth rate and size of a brood reaching maturity vary considerably even in the same climatic conditions, and it is believed that such variations depend on the growth of the ambrosia fungus which depends on the 
conditions of wood material.

6. Comparison between outbreeding and inbreeding rearing tests on $X$. germanus showed no difference in growth, development, and fertility of the insect. None-copulated young female was able to puncture the surface of wood material, but the pits were shallow and growth of ambrosia fungus spores did not occur.

7. The boring activity of $X$. germanus in the third generation was rather declined, and growth of ambrosia fungus became poor in this rearing tests. Some unknown substance contained in fresh wood material seems to stimulate growth of ambrosia fungus and promote the vitality of newly emerged female adults.

\section{REFERENCES}

KANEKo, T., Y. TAMAKI, and K. TAKagI (1965)

Japanese Jour. Appl. Ent. Zool. 9 : 23 28.

\section{EXPLANATION OF PLATE}

Plate I.

A. Rearing of Xyleborus compactus on steamsterilized tea twigs.

B. Rearing of Xyleborus germanus on steamsterilized tea twigs.

C. Rearing of Xyleborus germanus on steamsterilized tea roots. Matured larvae and ambrosia fungus spores are observed on the wood surface.

茶樹を加害するキクイムン類の生態

I ンイノコキクイムシ拈よびハンノキキクイムシの茶樹 殺菌材比よる飼育ととの経過習性について

$$
\text { 金農林省茶業試験場 }
$$

1. 茶樹の材を殺菌したものを飼料としてシイノコキ クイムシ (Xyleborus compxctus EIснноғF) および八 ンノキキクイムシ (Xyleborus germanus BLANFORD) を飼育し，これらの経過習性を調べた。

2. シイノコキクイムシは $25 \sim 26^{\circ} \mathrm{C}$ 恒温下で飼育し た場合, 卵から成虫まで17日を要した。すなわち，卵期 間が約 5 日，幼虫期間が 9 日（1令- -2 日， 2 令- -3 日， 3 令一 4 日）で， 3 令から蛹之なり，蛹期間は 4 日であ った。越冬中の雌成虫を殺菌茶枝に接種すると，22日目 に最初の成虫が羽化した。雌雄比はほぼ $3 ： 2 ， 1$ 頭当 たりの産卵数は $14 〜 16$ 粒であった。

3. ハンノキキクイムシは $24^{\circ} \mathrm{C}$ 恒温下で飼育すると, 卵から成虫まで15日を要した。すなわち，卵期間が 3 日 幼虫期間が 7 日（ 1 令 -2 日， 2 令一 2 日， 3 令 -3 日) で, 3 令から蛹化し,蛹期間は 5 日であった。雌雄此は第 1 世代成虫で $9: 1$, 第 2 世代成虫で $8 ： 1$ であった。

4. ハンノキキクイムシの生育虫数は, 殺菌根を飼料 とした場合は61.4䫓で，殺菌枝を飼料とした場 合には
40.8頭であった。これは根の水分含量が枝より高くアン ブロシヤ菌のはんしょくが旺盛であるためと考えられ る。

5. ハンノキキクイムシの雌成虫 1 頭当たりの産卵数 は33〜 50粒と考えられた。この雌成虫は，材の太さ，孔 道の大きさ，およびアンブロシャ菌のはんしょくの良否 によって産卵数を調節しているようである。

6. ハンノキキクイムシについて outbreeding 上 inbreedingの次世代に拉よぼす影響をしらべたとてろ， 生育虫数においては，てれら両者間にほとんど差異は認 められなかった。

7. ハンノキキクイムシの殺菌材による累代飼育の結 果では, 第 $1 \sim 2$ 世代とも生育は順調であったが, 第 3 世代ではアンブロシヤ菌のはんしょくが，きわめて悪か った。しかし，第 3 世代を生鮮根で飼育するとアンブロ シャ菌のはんしょくは順調であった。すなわち, 殺菌忉 による累代飼育では，何らかの物質不足によって雙成虫 が不活性化されるようである。 

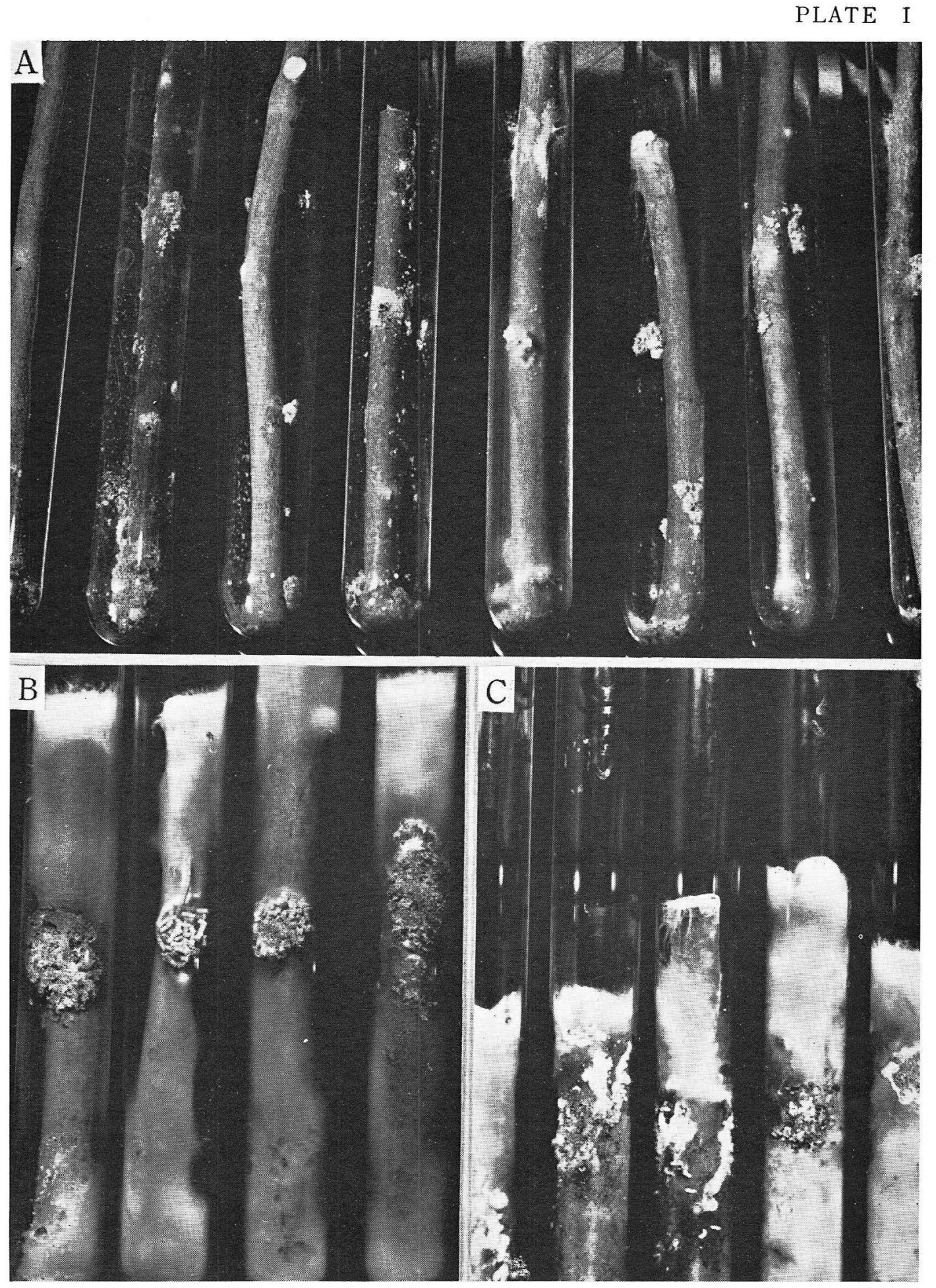